\title{
Environmental Pollution and Human Health Risks near a Hazardous Waste Landfill. Temporal Trends
}

\author{
Joaquim Rovira, Montse Mari, Marta Schuhmacher \\ Departament d'Enginyeria Quimica, Universitat Rovira i Virgili, Av. Països Catalans 26 \\ 43007 Tarragona, Catalonia, Spain \\ Martí Nadal, José L. Domingo \\ Laboratory of Toxicology and Environmental Health, IISPV, Universitat Rovira i Virgili, Sant Llorenç 21 \\ 43201 Reus, Catalonia, Spain \\ E-mail:marti.nadal@urv.cat \\ Received 10 October 2011; accepted 12 March 2012
}

\begin{abstract}
The human health risk assessment associated to the human exposure to polychlorinated dibenzo-p-dioxins and dibenzofurans (PCDD/Fs) and metals for the population living near a hazardous waste landfill (HWL) in Catalonia (Spain) is here presented. In summer of 2009 and 2010, two monitoring campaigns were performed by analyzing the levels of $\mathrm{PCDD} / \mathrm{Fs}$ and some elements ( $\mathrm{As}, \mathrm{Cd}, \mathrm{Cr}, \mathrm{Hg}, \mathrm{Ni}$, and $\mathrm{Pb}$ ) in air and soil samples around the HWL. Airborne pollutant levels were very low and without tendency found depending the distance to the facility, while higher levels were found in soils inside and close to the facility. Anyhow, current health risks associated with those contaminants were within acceptable ranges. Notwithstanding, it is recommended to continue with the monitoring program to detect any potential future change in the health risks.
\end{abstract}

Keywords: Hazardous waste landfill; PCDD/Fs; heavy metals; risk assessment; Castellolí (Catalonia, Spain).

\section{Introduction}

The European Directive 2008/98/EC establishes that the priorities for waste management are prevention, re-use, and recycling. If none of these options are feasible, the following step in the prioritization ranking is incineration with energy recovery (waste-to-energy). However, incineration is not the final step, as some byproducts (i.e., bottom ash, fly ash, and residues from air pollution control devices) may be produced. Among those, fly ashes can be especially dangerous as they may concentrate important amounts of metals and organic pollutants such as polychlorinated dibenzo- $p$-dioxins and dibenzofurans (PCDD/Fs) ${ }^{1-3}$ Dioxins and furans are well-known persistent, toxic, and bioaccumulative chemicals, included in the original list of the Stockholm Convention treaty, which aims at eliminating and/or restricting the environmental release of Persistent
Organic Pollutants (POPs). Because of their accumulation in soils, PCDD/Fs may be a problem for environment and human health. ${ }^{4}$ Moreover, ashes may also contain important quantities of elements such as arsenic, cadmium, or mercury, which have been associated with a wide range of toxic effects. Incineration ashes, together with other hazardous wastes, may pose substantial or potential threats to public health or the environment. ${ }^{5}$ Therefore, these residues must be properly disposed in controlled sites such as hazardous waste landfills (HWLs) in order to assure their harmlessness. In the last decade, the number of studies focused on assessing the potential health effects for people living nearby municipal solid waste incinerators (MSWIs) and other waste management plants has increased. ${ }^{6}$ Some other investigations have examined the human health effects in relation to residence near landfill sites, ${ }^{7}$ and findings seem not to 


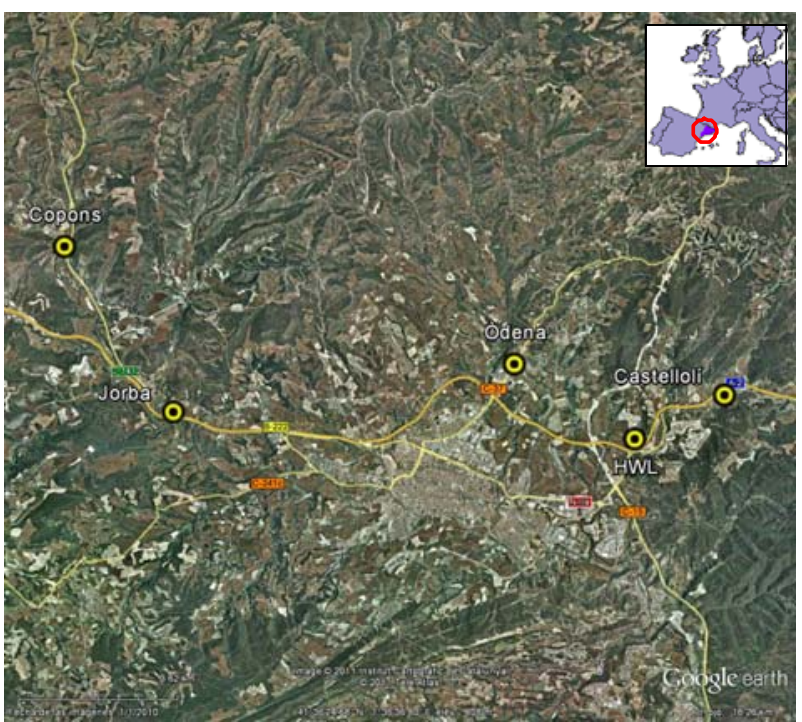

Fig. 1. Sampling area.

demonstrate an increased risk for the population. ${ }^{8}$ Nevertheless, a great concern still remains on this topic, as there are many uncertainties involved in the assessment of human exposure and health risks.

In 1998, a HWL located in the village of Castellolí (Barcelona, Catalonia, Spain), which in the past had been used as a chromate-derivatives deposit, started to receive other hazardous materials. Fly ashes from municipal solid waste incinerators (MSWIs) operating in Catalonia began to be stored there, together with other solid inert wastes and asbestos. The HWL of Castellolí is currently working according to the technical standards established in both the Catalan and European legislations regarding sealing criteria, leachate management, and water control. Despite the rigorous restraint measurements, the population and local authorities have shown some worries about that facility, including the potential environmental impact and adverse health effects derived from the continued operations in the facility. To address these concerns, in July and December 2007 a surveillance program was initiated. The main goal was to determine the environmental concentrations and human health risks derived from the exposure to metals and PCDD/Fs by the population living in the vicinity of the HWL of Castellolí. ${ }^{9}$ Air and soil samples were collected at sites located at different distances from the HWL. The levels of metals and PCDD/Fs were analyzed. That initial study concluded that the additional risks for the population living nearby the HWL were not significant. Nevertheless, a regular monitoring program was recommended in order to assure the proper operation of the facility. When evaluating the environmental impact of industrial facilities, the importance of performing temporal investigations, rather than specific campaigns, has been highlighted. ${ }^{10}$ Moreover, the use of various environmental monitors to provide complementary information is recommended to avoid a possible misinterpretation of the data. ${ }^{11}$ As result, two new monitoring campaigns were again performed in 2009 and 2010. In this paper, we present the results of the temporal trends in the levels of heavy metals and PCDD/Fs in soil and air samples collected around the HWL of Castellolí, as well as the trends regarding human health risks.

\section{Materials and methods}

\subsection{Sampling}

In July 2009 and 2010, air and soil samples were collected at the same 4 sampling points around the HWL of Castellolí, where samples had been collected in July and December 2007. ${ }^{9}$ During both campaigns, mean temperature was around $25^{\circ} \mathrm{C}$, no rainfall was recorded, and the wind origin was from south, southeast, and west directions. Samples were taken in the HWL (on site), in the nearest villages of Castellolí (519 inhabitants) and Òdena (3,442 inhabitants), and in the village of Jorba (823 inhabitants), considered as control. As in 2007, an additional soil sampling point was located in the village of Copons (320 inhabitants), considered also as control. Geologically, the terrain is dominated by the presence of clay rocks. This last village is unaffected by heavy traffic emissions of a main highway which crosses the area under study. Collection sites are shown in Figure 1. Sampling methods were recently described by Rovira et al. ${ }^{12}$ Briefly, air samples were collected by using highvolume active samplers (TE-1000 PUF for PCDD/Fs and TE-6070DV for metals adsorbed to $\mathrm{PM}_{10}$ (particulate matter), Tisch Environmental, Cleves, $\mathrm{OH}$, USA). Volumes sampled ranged between $600-700 \mathrm{~m}^{3}$ and 2,000-2,300 $\mathrm{m}^{3}$ for PCDD/Fs and $\mathrm{PM}_{10}$, respectively. In turn, each soil sample consisted on four subsamples collected within an area of $25 \mathrm{~m}^{2}$, taken from the upper $5 \mathrm{~cm}$ of ground and stored in polyethylene bags. The bulked samples were dried at room temperature and sieved through a $2 \mathrm{~mm}$ mesh screen until analysis. 


\subsection{Analytical methods}

The concentrations of arsenic (As), cadmium (Cd), chromium $(\mathrm{Cr})$, mercury $(\mathrm{Hg})$, nickel $(\mathrm{Ni})$, and lead $(\mathrm{Pb})$ were determined in air and soil samples. Metal levels were measured by inductively coupled plasma spectrometry (ICP-MS, Perkin Elmer Elan 6000) after sample digestion. For soils, $0.5 \mathrm{~g}$ of sample were digested with $5 \mathrm{~mL}$ of $\mathrm{HNO}_{3}$ (65\% Suprapur, E. Merck, Darmstadt, Germany) in a Milestone Start D Microwave Digestion System for $10 \mathrm{~min}$ until reaching $165^{\circ} \mathrm{C}$, and kept at this temperature for $20 \mathrm{~min}$. For air, around 6.3 $\mathrm{cm}^{2}$ of each filter was digested with $2 \mathrm{~mL} \mathrm{HNO}_{3}(65 \%$ Suprapur, E. Merck) and $3 \mathrm{~mL}$ HF (37.5\%, Panreac SA, Barcelona, Spain) in hermetic Teflon bombs. In both cases, blank and control samples, as well as reference materials (Soil, Loamy clay, CRM-052, Resource Technology Corporation, Laramie, WY, USA), were used to check the accuracy of the instrumental methods. Detailed additional information concerning the analytical procedures can be found elsewhere. ${ }^{13}$ The recovery percentages were $86-124 \%$ and $82-101 \%$ for soils and air, respectively. procedure followed on micro columns of silica gel and alumina. The final extract was again spiked with isotopic labelled internal standards and then analyzed by HRGC-HRMS (Agilent 6890-Waters Autospec Ultima). The recovery percentage ranges were $58-107 \%$ and 59 $121 \%$ for soils and air, respectively. In this study, total $\mathrm{PCDD} / \mathrm{F}$ concentrations were calculated by using the most recent data of World Health Organization Toxic Equivalency Factors (WHO-TEFs), ${ }^{14}$ Consequently, levels are given as WHO Toxic Equivalents (WHOTEQ). In terms of comparison, values from the legislation and old studies are given in International Toxic Equivalents (I-TEQ), as these were calculated according to the old I-TEFs.

\subsection{Human health risks}

The concentrations of PCDD/Fs and metals in soils and air were used to estimate the human exposure and health risks at the different sampling points in/around the HWL in both periods of time (2009 and 2010). Three different routes of exposure were considered for the pollutants: soil ingestion, dermal contact, and air

Table 1. Levels of metals and PCDD/Fs in air and soil samples collected around the HWL in July 2009 and 2010.

\begin{tabular}{|c|c|c|c|c|c|c|c|c|c|c|}
\hline & \multicolumn{5}{|c|}{ July 2009} & \multicolumn{5}{|c|}{ July 2010} \\
\hline & HWL & Castellolí & Òdena & Jorba & Copons & HWL & Castellolí & Òdena & Jorba & Copons \\
\hline \multicolumn{11}{|l|}{ Air } \\
\hline As & 0.32 & 0.30 & 0.28 & 0.28 & NA & 0.32 & 0.19 & 0.22 & $<0.02$ & NA \\
\hline Cd & 0.08 & $<0.01$ & $<0.01$ & 0.05 & NA & 0.06 & $<0.01$ & 0.06 & $<0.01$ & NA \\
\hline $\mathrm{Cr}$ & $<0.08$ & $<0.08$ & $<0.08$ & $<0.08$ & NA & $<0.08$ & $<0.08$ & 0.30 & 2.50 & NA \\
\hline Hg & $<0.03$ & $<0.03$ & $<0.03$ & $<0.03$ & NA & $<0.03$ & $<0.03$ & $<0.03$ & $<0.03$ & NA \\
\hline $\mathrm{Ni}$ & 2.04 & 14.6 & 0.76 & 2.08 & NA & 3.48 & 1.23 & 3.58 & 1.07 & NA \\
\hline $\mathbf{P b}$ & 4.81 & 2.70 & 4.65 & 3.06 & NA & 3.68 & 1.28 & 3.16 & 1.24 & NA \\
\hline PCDD/Fs & 6.70 & 3.23 & 3.56 & 2.45 & NA & 6.93 & 5.41 & 4.39 & 9.86 & NA \\
\hline \multicolumn{11}{|l|}{ Soil } \\
\hline As & 10.2 & 9.47 & 1.83 & 1.75 & 1.02 & 8.83 & 7.64 & 1.95 & 3.95 & 1.18 \\
\hline Cd & 0.39 & 0.14 & 0.07 & 0.07 & 0.05 & 0.60 & 0.14 & 0.08 & 0.07 & 0.06 \\
\hline $\mathrm{Cr}$ & 27.0 & 12.7 & 8.83 & 11.9 & 11.3 & 52.2 & 16.1 & 9.18 & 13.7 & 9.48 \\
\hline Hg & $<0.10$ & $<0.10$ & $<0.10$ & $<0.10$ & $<0.10$ & $<0.10$ & $<0.10$ & $<0.10$ & $<0.10$ & $<0.10$ \\
\hline $\mathrm{Ni}$ & 16.2 & 12.6 & 4.18 & 5.49 & 3.66 & 19.1 & 15.3 & 4.69 & 8.90 & 3.87 \\
\hline $\mathbf{P b}$ & 50.0 & 10.5 & 7.74 & 9.75 & 8.80 & 50.1 & 10.5 & 8.44 & 11.3 & 8.29 \\
\hline PCDD/Fs & NA & NA & NA & NA & NA & 1.07 & 0.13 & 0.20 & 0.16 & 0.13 \\
\hline
\end{tabular}

NA: Not analyzed. Units. Air: PCDD/Fs: fg WHO-TEQ $\cdot \mathrm{m}^{-3} ;$ metals: $\mathrm{ng} \cdot \mathrm{m}^{-3}$; Soil: PCDD/Fs: $\mathrm{ng}$ WHO-TEQ $\cdot \mathrm{kg}^{-1} ; \mathrm{metals:}^{\mathrm{mg}} \cdot \mathrm{kg}^{-1}$

On the other hand, PCDD/F concentrations were determined by high-resolution gas chromatography/ high-resolution mass spectrometry (HRGC/HRMS), following the German VDI 3499 method. Prior to extraction, ${ }^{13} \mathrm{C}_{12}$-PCDD/F congeners were spiked as recovery internal standards to detect any potential loss during the process. Samples were extracted with toluene by accelerated solvent extraction (ASE). The extract was subsequently subjected to an acid/base clean-up inhalation. The equations to calculate exposure and risks were recently reported. ${ }^{15}$ The non-carcinogenic risks were calculated using the Hazard Quotient (HQ), which is defined as the quotient between the predicted exposure and the respective reference dose. Cancer risks were calculated by multiplying the predicted exposure by the respective slope factor. Dermal reference doses were calculated multiplying the respective oral reference dose by the gastrointestinal absorption factor, 
while dermal slope factors were calculated by dividing the respective oral slope factor by the gastrointestinal absorption factor. ${ }^{16}$ Reference doses, slope factors and gastrointestinal factors were taken from the Risk Assessment Information System database. ${ }^{17} \mathrm{PCDD} / \mathrm{F}$ exposure was estimated by calculating separately the exposure to each one of the $17 \mathrm{PCDD} / \mathrm{F}$ congeners and summing the results, which were the basis for the health risk assessment.

\section{Results and discussion}

\subsection{Air concentrations of metals and PCDD/Fs}

Table 1 summarizes the levels of metals and PCDD/Fs in air samples collected around the HWL in 2009 and 2010. Mercury concentration in all air samples was below its detection limit $\left(<0.03 \mathrm{ng} \cdot \mathrm{m}^{-3}\right)$ in both sampling periods. Cadmium was detected only in the HWL $\left(0.08 \mathrm{ng} \cdot \mathrm{m}^{-3}\right)$ and Jorba $\left(0.05 \mathrm{ng} \cdot \mathrm{m}^{-3}\right)$ sampling sites in 2009, as well as in the HWL and Òdena (0.06 $\mathrm{ng} \cdot \mathrm{m}^{-3}$ in both sampling sites) in 2010. Chromium levels were below detection limit $\left(<0.08 \mathrm{ng} \cdot \mathrm{m}^{-3}\right)$ in most samples collected in 2009 and 2010, with the only exception of Òdena $\left(0.30 \mathrm{ng} \cdot \mathrm{m}^{-3}\right)$ and Jorba (blank site) $\left(2.50 \mathrm{ng} \cdot \mathrm{m}^{-3}\right)$ in 2010. In 2009, As levels in air were similar in the four sampling sites, ranging from 0.28 to $0.32 \mathrm{ng} \cdot \mathrm{m}^{-3}$, while in 2010 very similar levels were found everywhere, with the exception of Jorba, for which As was undetected. The highest metal concentrations corresponded to $\mathrm{Ni}$ and $\mathrm{Pb}$ (14.6 and $4.81 \mathrm{ng} \cdot \mathrm{m}^{-3}$, respectively). Anyhow, these levels are still below the guidelines established by the EU legislation for $\mathrm{Pb}, \mathrm{As}, \mathrm{Cd}$, and $\mathrm{Ni}$, which were set at 500, 6, 5, and $20 \mathrm{ng} \cdot \mathrm{m}^{-3}$, respectively.

The variation percentages with respect to data from the baseline survey (July 2007) are shown in Table 2. For these calculations, Castellolí and Òdena were grouped as near sites, while Jorba and Copons as control sites. Heterogeneous fluctuations were observed, and a common increase in the levels of the near-site was not noted. Those variations would be more related to point peaks of unknown source associated with local emission sources, rather than due to the influence of the facility.

The levels of PCDD/Fs in air collected in the 2009 survey ranged from 2.45 to $6.70 \mathrm{fg} \mathrm{WHO}-\mathrm{TEQ} \cdot \mathrm{m}^{-3}$, with a mean concentration of $3.99 \mathrm{fg} \mathrm{WHO}-\mathrm{TEQ} \cdot \mathrm{m}^{-3}$ (Table 1). In 2010, PCDD/F values were between 4.39 and $9.86 \mathrm{fg} \mathrm{WHO}-\mathrm{TEQ} \cdot \mathrm{m}^{-3}$, being the arithmetic mean
$6.65 \mathrm{fg} \mathrm{WHO}-\mathrm{TEQ} \cdot \mathrm{m}^{-3}$. The concentration of PCDD/Fs increased at the HWL sampling site in the periods 20072009 and 2007-2010 (Table 2), while different variations were observed in the remaining areas. Anyhow, the concentrations within and around the HWL were very low in comparison with recent data from various national and international studies. PCDD/F ranges of 5-7 $\mathrm{fg} \mathrm{WHO}-\mathrm{TEQ} \cdot \mathrm{m}^{-3}, 5-45 \mathrm{fg} \mathrm{I-TEQ} \cdot \mathrm{m}^{-3}, 3-$ $172 \mathrm{fg}$ WHO TEQ $\cdot \mathrm{m}^{-3}$, and 22-125 $\mathrm{fg} \mathrm{I-TEQ} \cdot \mathrm{m}^{-3}$ were found in ambient air of rural areas of South Catalonia, Spain, Northeast China, and Italy, respectively. ${ }^{18-20}$

Table 2. Temporal trends of the concentrations of metals and PCDD/Fs

\begin{tabular}{lcccccc}
\hline & \multicolumn{2}{c}{ \% Var July 2007-2009 } & \multicolumn{3}{c}{ \% Var July 2007-2010 } \\
& HWL & $\begin{array}{c}\text { Near } \\
\text { Site }\end{array}$ & $\begin{array}{c}\text { Control } \\
\text { site }\end{array}$ & HWL & $\begin{array}{c}\text { Near } \\
\text { Site }\end{array}$ & $\begin{array}{c}\text { Control } \\
\text { site }\end{array}$ \\
\hline Air & & & & & & \\
As & -24 & 287 & 367 & -24 & 173 & -83 \\
Cd & 60 & - & 900 & 20 & 550 & - \\
Cr & -99 & - & - & -99 & 325 & 6150 \\
Hg & - & - & - & - & - & - \\
Ni & -42 & 186 & -5 & -1 & -10 & -51 \\
Pb & 3908 & 3873 & 61100 & 2967 & 2300 & 6150 \\
PCDD/Fs & 72 & -9 & -37 & 78 & 31 & 153 \\
\hline Soil & & & & & & \\
As & 357 & 147 & 164 & 296 & 110 & 389 \\
Cd & 22 & -16 & 50 & 88 & -12 & 63 \\
Cr & 273 & 18 & 41 & 621 & 39 & 41 \\
Hg & - & - & - & - & - & - \\
Ni & 174 & 28 & 59 & 223 & 52 & 121 \\
Pb & 169 & -52 & 7 & 170 & -50 & 13 \\
PCDD/Fs & NA & NA & NA & -29 & -85 & -15 \\
\hline Near site: Castellolín and Oेdena; Control site: Soil: Jorba + Copons, Air: Jorba.
\end{tabular}

\subsection{Soil concentrations of metals and PCDD/Fs}

The concentrations of metals and PCDD/Fs in soil samples collected in July 2009 and July 2010 in/around the HWL are shown in Table 1. In general terms, the HWL sampling site presented the highest metal concentrations. However, all metals were below the most restrictive limits established by the Catalan Agency of Waste to protect human health. ${ }^{21}$ When compared with the European Geochemical Atlas developed by EuroGeoSurveys, ${ }^{22}$ only the concentrations of $\mathrm{Cd}, \mathrm{Cr}$, and $\mathrm{Pb}$ inside the HWL were higher than baseline topsoil levels. In the 2009 and 2010 surveys, $\mathrm{Hg}$ concentrations in all soil sampling points were below its detection limit $\left(<0.10 \mathrm{mg} \cdot \mathrm{kg}^{-1}\right)$. In contrast, $\mathrm{Pb}$ and $\mathrm{Cr}$ presented the highest levels. Lead concentrations ranged between 7.74 and $50.1 \mathrm{mg} \cdot \mathrm{kg}^{-1}$ in both sampling campaigns, while $\mathrm{Cr}$ levels ranged from 8.83 to $52.2 \mathrm{mg} \cdot \mathrm{kg}^{-1}$, with slightly higher values in 
2010. Notwithstanding, the concentrations of metals in soils found at the different sites in 2009 and 2010 were similar, being generally higher at the HWL sampling site, followed by Castellolí. Odena and the two reference locations (Jorba and Copons) presented the lowest levels. Lead was the only element which did not follow this pattern. Lead level in Castellolí soils was not different from that found in other sites. When assessing the temporal trends in the soil concentrations, all metals presented important increases in the HWL and the reference sampling sites, being a first indication that these raises could be more associated to meteorological conditions and/or other sources, rather than to the presence of the HWL. Finally, moderate decreases were noted for $\mathrm{Pb}$ and $\mathrm{Cd}$ at the near sites during the period 2007-2010.

Because soils are a cumulative matrix, $\mathrm{PCDD} / \mathrm{F}$ levels were only measured in July 2010. The highest concentrations of PCDD/Fs in soils were noted at the HWL sampling site (1.07 ng WHO-TEQ $\cdot \mathrm{kg}^{-1}$ ), while those found in the remaining sites were very similar (range: $0.13-0.20 \mathrm{ng}$ WHO-TEQ $\cdot \mathrm{kg}^{-1}$ ). Anyway, the levels of PCDD/Fs in soils at the HWL were generally lower than the diverse international screening levels available for PCDD/Fs. Threshold values of $10 \mathrm{I}-\mathrm{TEQ}$ $\mathrm{ng} \cdot \mathrm{kg}^{-1}$ in Austria and Finland, and $4 \mathrm{I}-\mathrm{TEQ} \mathrm{ng} \cdot \mathrm{kg}^{-1}$ in Canada, ${ }^{23}$ have been established to regulate the levels of $\mathrm{PCDD} / \mathrm{Fs}$ in agricultural soils. The $\mathrm{PCDD} / \mathrm{F}$ congener profile (as contribution percentage) in soil samples collected in the vicinity of the HWL is depicted in Figure 2. The HWL sample presented the lowest OCDD contribution (near 30\%), in comparison with the other sites where this was the predominant congener $(>50 \%)$. In contrast, OCDF showed an opposite profile, being proportionally higher inside the landfill. When evaluating the temporal variation between the baseline (2007) and the last (2010) surveys (Table 2), a decrease in the PCDD/F levels was noted in all sampling points, which was being especially remarkable at the closest sites.

\subsection{Principal Component Analysis (PCA)}

In recent years, the use of statistical and mathematical tools to process amounts of data has become a standard practice in environmental studies. Self-organizing maps and principal component analysis (PCA) are good examples. $^{24,25}$ In the present investigation, a PCA was performed in order to compare the profiles of metals and PCDD/Fs found in soils of the different sites, and consequently, to investigate the potential influence of the HWL as a pollutant source in the surrounding environment. Soil samples were chosen to perform the PCA as it is a cumulative matrix, contrasting with air, which is a more variable environmental compartment and highly dependent on the meteorological conditions during sampling. Those PCDD/F congeners and metals showing concentrations below their respective detection limits in more than $50 \%$ of the samples, were not taken into account. The whole set of soil samples, corresponding to July and December of 2007 and July of 2010, was included. PCA provided a threedimensional model with PC1, PC2, and PC3 explaining $60 \%, 19 \%$ and $14 \%$ of the total variance, respectively.

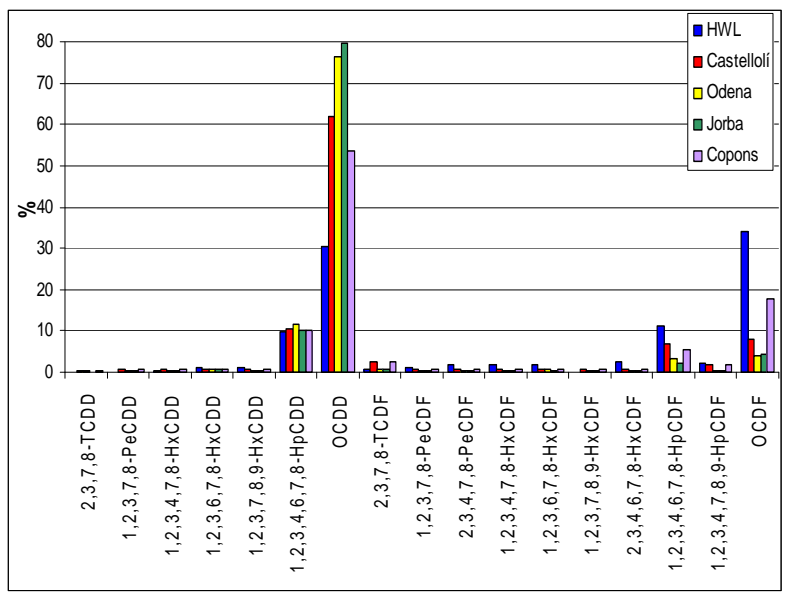

Fig. 2. PCDD/F congener profile in soil samples collected in 2010 around the HWL.

PC1 was positively correlated with penta-, hexa-, heptaand octa-furans, as well as with hexaCDD. PC2 was positively correlated with $\mathrm{As}, \mathrm{Cr}$, and $\mathrm{Ni}$, while $\mathrm{PC} 3$ was positively correlated with $1,2,3,4,6,7,8-\mathrm{HpCDD}$ and OCDD. The score plot (Figure 3 ) showed a main cluster containing most of the sampling points, independently of their distance to the HWL. However, those samples collected inside the HWL showed a different pattern, indicating that this particular zone could be somehow impacted by some pollutants. Therefore, further studies should corroborate the lack of increase in the environmental burden of $\mathrm{PCDD} / \mathrm{Fs}$, as this issue could have important implications for the HWL workers potentially exposed to these contaminants. 


\subsection{Human health risks}

Table 3 shows the exposure to PCDD/Fs and metals through 3 routes at the different sampling points. The main pathways of metal exposure were soil and dust ingestion, with percentages of contribution between $67 \%$ and $95 \%$, except for As, whose predominant route was dermal absorption (53\%). Regarding PCDD/Fs, only inhalation was evaluated in 2009 since soil concentrations were not determined that year. In 2010, the major route of exposure to $\mathrm{PCDD} / \mathrm{Fs}$ was soil ingestion in the HWL, while air inhalation was the leading pathway in residential sites, with individual contributions from $44 \%$ to $76 \%$. Inhalation and dermal contact are 2 routes of exposure to POPs in general, and

Table 3. Predicted daily exposure for metals $\left(\mathrm{mg} \cdot \mathrm{kg}^{-1} \cdot \mathrm{day}^{-1}\right)$ and PCDD/Fs (ng WHO-TEQ $\left.\cdot \mathrm{kg}^{-1} \cdot \mathrm{day}^{-1}\right)$ for the population living around the HWL of Castellolí, Catalonia, Spain.

\begin{tabular}{|c|c|c|c|c|c|c|c|c|c|c|}
\hline & \multicolumn{5}{|c|}{$\begin{array}{l}\text { July } 2009 \\
\end{array}$} & \multicolumn{5}{|c|}{ July 2010} \\
\hline & HWL & Castellolí & Òdena & Jorba & Copons & HWL & Castellolí & Òdena & Jorba & Copons \\
\hline \multicolumn{11}{|l|}{ Ingestion } \\
\hline As & $1.59 \mathrm{E}-05$ & $1.48 \mathrm{E}-05$ & $2.86 \mathrm{E}-06$ & $2.73 \mathrm{E}-06$ & $1.59 \mathrm{E}-06$ & $1.38 \mathrm{E}-05$ & $1.19 \mathrm{E}-05$ & $3.05 \mathrm{E}-06$ & $6.17 \mathrm{E}-06$ & $1.84 \mathrm{E}-06$ \\
\hline$C d$ & $6.09 \mathrm{E}-07$ & $2.19 \mathrm{E}-07$ & $1.09 \mathrm{E}-07$ & $1.09 \mathrm{E}-07$ & 7.81E-08 & $9.37 \mathrm{E}-07$ & $2.19 \mathrm{E}-07$ & $1.25 \mathrm{E}-07$ & $1.09 \mathrm{E}-07$ & 9.37E-08 \\
\hline $\mathrm{Cr}$ & 4.22E-05 & $1.98 \mathrm{E}-05$ & $1.38 \mathrm{E}-05$ & $1.86 \mathrm{E}-05$ & $1.76 \mathrm{E}-05$ & $8.15 \mathrm{E}-05$ & $2.51 \mathrm{E}-05$ & $1.43 \mathrm{E}-05$ & $2.14 \mathrm{E}-05$ & $1.48 \mathrm{E}-05$ \\
\hline $\mathrm{Hg}$ & $\mathrm{NC}$ & $\mathrm{NC}$ & $\mathrm{NC}$ & $\mathrm{NC}$ & $\mathrm{NC}$ & $\mathrm{NC}$ & $\mathrm{NC}$ & $\mathrm{NC}$ & $\mathrm{NC}$ & $\mathrm{NC}$ \\
\hline $\mathrm{Ni}$ & $2.53 \mathrm{E}-05$ & $1.97 \mathrm{E}-05$ & $6.53 \mathrm{E}-06$ & $8.57 \mathrm{E}-06$ & $5.72 \mathrm{E}-06$ & $2.98 \mathrm{E}-05$ & $2.39 \mathrm{E}-05$ & 7.32E-06 & $1.39 \mathrm{E}-05$ & $6.04 \mathrm{E}-06$ \\
\hline$P b$ & 7.81E-05 & $1.64 \mathrm{E}-05$ & $1.21 \mathrm{E}-05$ & $1.52 \mathrm{E}-05$ & $1.37 \mathrm{E}-05$ & 7.82E-05 & $1.64 \mathrm{E}-05$ & $1.32 \mathrm{E}-05$ & $1.76 \mathrm{E}-05$ & $1.29 \mathrm{E}-05$ \\
\hline$P C D D / F s$ & NA & NA & NA & NA & NA & $8.26 \mathrm{E}-11$ & $8.09 \mathrm{E}-12$ & $2.86 \mathrm{E}-11$ & $3.13 \mathrm{E}-11$ & $7.86 \mathrm{E}-12$ \\
\hline \multicolumn{11}{|l|}{ Dermal } \\
\hline As & $1.81 \mathrm{E}-05$ & $1.68 \mathrm{E}-05$ & $3.25 \mathrm{E}-06$ & $3.11 \mathrm{E}-06$ & $1.81 \mathrm{E}-06$ & $1.57 \mathrm{E}-05$ & $1.36 \mathrm{E}-05$ & $3.46 \mathrm{E}-06$ & $7.01 \mathrm{E}-06$ & $2.09 \mathrm{E}-06$ \\
\hline$C d$ & $2.16 \mathrm{E}-07$ & $7.77 \mathrm{E}-08$ & 3.88E-08 & $3.88 \mathrm{E}-08$ & $2.77 \mathrm{E}-08$ & 3.33E-07 & $7.77 \mathrm{E}-08$ & 4.44E-08 & $3.88 \mathrm{E}-08$ & $3.33 \mathrm{E}-08$ \\
\hline $\mathrm{Cr}$ & $1.50 \mathrm{E}-06$ & $7.05 \mathrm{E}-07$ & $4.90 \mathrm{E}-07$ & $6.60 \mathrm{E}-07$ & $6.27 \mathrm{E}-07$ & $2.90 \mathrm{E}-06$ & $8.93 \mathrm{E}-07$ & $5.09 \mathrm{E}-07$ & 7.60E-07 & $5.26 \mathrm{E}-07$ \\
\hline $\mathrm{Hg}$ & $\mathrm{NC}$ & $\mathrm{NC}$ & $\mathrm{NC}$ & $\mathrm{NC}$ & $\mathrm{NC}$ & $\mathrm{NC}$ & $\mathrm{NC}$ & $\mathrm{NC}$ & $\mathrm{NC}$ & $\mathrm{NC}$ \\
\hline $\mathrm{Ni}$ & $8.99 \mathrm{E}-07$ & $6.99 \mathrm{E}-07$ & 2.32E-07 & $3.05 \mathrm{E}-07$ & 2.03E-07 & $1.06 \mathrm{E}-06$ & 8.49E-07 & $2.60 \mathrm{E}-07$ & 4.94E-07 & $2.15 \mathrm{E}-07$ \\
\hline$P b$ & $2.77 \mathrm{E}-06$ & 5.83E-07 & 4.29E-07 & $5.41 \mathrm{E}-07$ & $4.88 \mathrm{E}-07$ & $2.78 \mathrm{E}-06$ & $5.83 \mathrm{E}-07$ & $4.68 \mathrm{E}-07$ & $6.27 \mathrm{E}-07$ & 4.60E-07 \\
\hline$P C D D / F s$ & NA & NA & NA & NA & NA & $2.93 \mathrm{E}-11$ & $2.87 \mathrm{E}-12$ & $1.02 \mathrm{E}-11$ & $1.11 \mathrm{E}-11$ & $2.79 \mathrm{E}-12$ \\
\hline \multicolumn{11}{|l|}{ Inhalation } \\
\hline As & $8.77 \mathrm{E}-08$ & $8.22 \mathrm{E}-08$ & 7.67E-08 & 7.67E-08 & NA & $8.77 \mathrm{E}-08$ & $5.21 \mathrm{E}-08$ & $6.03 \mathrm{E}-08$ & $\mathrm{NC}$ & NA \\
\hline$C d$ & $2.19 \mathrm{E}-08$ & $\mathrm{NC}$ & $\mathrm{NC}$ & $5.48 \mathrm{E}-09$ & NA & $1.64 \mathrm{E}-08$ & $\mathrm{NC}$ & $1.64 \mathrm{E}-08$ & $\mathrm{NC}$ & NA \\
\hline $\mathrm{Cr}$ & $\mathrm{NC}$ & $\mathrm{NC}$ & $\mathrm{NC}$ & $\mathrm{NC}$ & NA & $\mathrm{NC}$ & $\mathrm{NC}$ & $8.22 \mathrm{E}-08$ & $6.85 \mathrm{E}-07$ & NA \\
\hline $\mathrm{Hg}$ & $\mathrm{NC}$ & $\mathrm{NC}$ & $\mathrm{NC}$ & $\mathrm{NC}$ & NA & $\mathrm{NC}$ & $\mathrm{NC}$ & $\mathrm{NC}$ & $\mathrm{NC}$ & NA \\
\hline $\mathrm{Ni}$ & $5.59 \mathrm{E}-07$ & $4.00 \mathrm{E}-06$ & $5.70 \mathrm{E}-07$ & $2.08 \mathrm{E}-07$ & NA & $9.53 \mathrm{E}-07$ & 3.37E-07 & $9.81 \mathrm{E}-07$ & $2.93 \mathrm{E}-07$ & NA \\
\hline$P b$ & $1.32 \mathrm{E}-06$ & $7.40 \mathrm{E}-07$ & $1.27 \mathrm{E}-06$ & $8.38 \mathrm{E}-07$ & NA & $1.01 \mathrm{E}-06$ & $3.51 \mathrm{E}-07$ & $8.66 \mathrm{E}-07$ & $3.40 \mathrm{E}-07$ & NA \\
\hline$P C D D / F s$ & $2.18 \mathrm{E}-11$ & $1.93 \mathrm{E}-11$ & $2.37 \mathrm{E}-11$ & $1.48 \mathrm{E}-11$ & NA & 3.54E-11 & $2.31 \mathrm{E}-11$ & $3.00 \mathrm{E}-11$ & 4. $44 \mathrm{E}-11$ & NA \\
\hline
\end{tabular}

Table 4. Non-carcinogenic and carcinogenic risks (adimensional) of metals and PCDD/Fs.

\begin{tabular}{|c|c|c|c|c|c|c|c|c|c|c|}
\hline & \multicolumn{5}{|c|}{ July 2009} & \multicolumn{5}{|c|}{ July 2010} \\
\hline & HWL & Castellolí & Òdena & Jorba & Copons $^{\mathrm{b}}$ & HWL & Castellolí & Òdena & Jorba & Copons $^{\mathrm{b}}$ \\
\hline \multicolumn{11}{|l|}{$\mathbf{H Q}_{\text {Total }}$} \\
\hline As & $1.34 \mathrm{E}-01$ & $1.25 \mathrm{E}-01$ & $3.83 \mathrm{E}-02$ & $3.74 \mathrm{E}-02$ & $1.13 \mathrm{E}-02$ & $1.42 \mathrm{E}-01$ & $1.17 \mathrm{E}-01$ & 4.29E-02 & $5.27 \mathrm{E}-02$ & $1.58 \mathrm{E}-02$ \\
\hline $\mathrm{Cd}$ & $5.70 \mathrm{E}-03$ & $1.77 \mathrm{E}-03$ & $1.37 \mathrm{E}-03$ & $8.86 \mathrm{E}-04$ & $6.33 \mathrm{E}-04$ & $9.80 \mathrm{E}-03$ & $2.13 \mathrm{E}-03$ & $1.91 \mathrm{E}-03$ & $1.06 \mathrm{E}-03$ & $9.11 \mathrm{E}-04$ \\
\hline $\mathrm{Cr}$ & $3.40 \mathrm{E}-02$ & $1.60 \mathrm{E}-02$ & $1.11 \mathrm{E}-02$ & $1.50 \mathrm{E}-02$ & $1.42 \mathrm{E}-02$ & $3.46 \mathrm{E}-02$ & $1.36 \mathrm{E}-02$ & $1.12 \mathrm{E}-02$ & 4.04E-02 & 8.03E-03 \\
\hline $\mathrm{Hg}$ & $\mathrm{NC}$ & $\mathrm{NC}$ & $\mathrm{NC}$ & $\mathrm{NC}$ & $\mathrm{NC}$ & $\mathrm{NC}$ & $\mathrm{NC}$ & $\mathrm{NC}$ & $\mathrm{NC}$ & $\mathrm{NC}$ \\
\hline $\mathrm{Ni}$ & $9.46 \mathrm{E}-02$ & $5.36 \mathrm{E}-02$ & 8.98E-02 & $5.95 \mathrm{E}-02$ & $5.40 \mathrm{E}-04$ & $8.22 \mathrm{E}-02$ & $3.00 \mathrm{E}-02$ & 8.29E-02 & $2.56 \mathrm{E}-02$ & 4.36E-04 \\
\hline $\mathrm{Pb}$ & $2.31 \mathrm{E}-02$ & $4.85 \mathrm{E}-03$ & $3.58 \mathrm{E}-03$ & $4.50 \mathrm{E}-03$ & 4.07E-03 & $2.75 \mathrm{E}-02$ & $5.76 \mathrm{E}-03$ & 4.63E-03 & $6.20 \mathrm{E}-03$ & $4.55 \mathrm{E}-03$ \\
\hline $\mathrm{PCDD} / \mathrm{Fs}$ & $1.93 \mathrm{E}-04^{\mathrm{a}}$ & $9.31 \mathrm{E}-05^{\mathrm{a}}$ & $1.02 \mathrm{E}-04^{\mathrm{a}}$ & $7.05 \mathrm{E}-05^{\mathrm{a}}$ & NA & $3.88 \mathrm{E}-03$ & $5.72 \mathrm{E}-04$ & $1.11 \mathrm{E}-03$ & $1.14 \mathrm{E}-03$ & $4.34 \mathrm{E}-04$ \\
\hline \multicolumn{11}{|l|}{$\begin{array}{c}\text { Cancer risk } \\
\text { Ingestion }\end{array}$} \\
\hline As & $1.02 \mathrm{E}-05$ & $9.51 \mathrm{E}-06$ & $1.84 \mathrm{E}-06$ & $1.76 \mathrm{E}-06$ & $1.02 \mathrm{E}-06$ & $8.86 \mathrm{E}-06$ & 7.67E-06 & $1.96 \mathrm{E}-06$ & $3.97 \mathrm{E}-06$ & $1.18 \mathrm{E}-06$ \\
\hline $\begin{array}{l}\mathrm{PCDD} / \mathrm{Fs} \\
\text { Dermal }\end{array}$ & NA & NA & NA & NA & NA & $9.27 \mathrm{E}-08$ & $1.13 \mathrm{E}-08$ & $1.70 \mathrm{E}-08$ & $1.41 \mathrm{E}-08$ & $1.12 \mathrm{E}-08$ \\
\hline As & $2.72 \mathrm{E}-05$ & $2.52 \mathrm{E}-05$ & $4.87 \mathrm{E}-06$ & $4.66 \mathrm{E}-06$ & $2.72 \mathrm{E}-06$ & $1.01 \mathrm{E}-05$ & 8.72E-06 & $2.23 \mathrm{E}-06$ & $4.51 \mathrm{E}-06$ & $1.35 \mathrm{E}-06$ \\
\hline $\begin{array}{l}\mathrm{PCDD} / \mathrm{Fs} \\
\text { Inhalation }\end{array}$ & NA & NA & NA & NA & NA & $3.29 \mathrm{E}-08$ & 4.01E-09 & 6.03E-09 & $5.02 \mathrm{E}-09$ & 3.97E-09 \\
\hline As & $5.65 \mathrm{E}-07$ & $5.30 \mathrm{E}-07$ & $4.95 \mathrm{E}-07$ & $4.95 \mathrm{E}-07$ & NA & $5.65 \mathrm{E}-07$ & $3.36 \mathrm{E}-07$ & $3.89 \mathrm{E}-07$ & $\mathrm{NC}$ & NA \\
\hline $\mathrm{Cd}$ & 5.92E-08 & $1.48 \mathrm{E}-08$ & $3.70 \mathrm{E}-08$ & $1.48 \mathrm{E}-08$ & NA & $4.44 \mathrm{E}-08$ & $\mathrm{NC}$ & 4.4E-08 & $\mathrm{NC}$ & NA \\
\hline $\mathrm{Cr}(\mathrm{VI})$ & $\mathrm{NC}$ & $\mathrm{NC}$ & $\mathrm{NC}$ & $\mathrm{NC}$ & NA & $\mathrm{NC}$ & $\mathrm{NC}$ & $1.73 \mathrm{E}-06$ & $1.44 \mathrm{E}-05$ & NA \\
\hline $\mathrm{Ni}$ & $2.01 \mathrm{E}-07$ & $1.44 \mathrm{E}-06$ & $2.05 \mathrm{E}-07$ & $1.25 \mathrm{E}-08$ & NA & $3.43 \mathrm{E}-07$ & $1.21 \mathrm{E}-07$ & $3.53 \mathrm{E}-07$ & $1.06 \mathrm{E}-07$ & NA \\
\hline $\mathrm{PCDD} / \mathrm{Fs}$ & $1.05 \mathrm{E}-07$ & $5.05 \mathrm{E}-08$ & $5.56 \mathrm{E}-08$ & $3.83 \mathrm{E}-08$ & NA & $1.08 \mathrm{E}-07$ & $6.85 \mathrm{E}-08$ & $8.44 \mathrm{E}-08$ & $1.54 \mathrm{E}-07$ & NA \\
\hline
\end{tabular}

Published by Atlantis Press

Copyright: the authors 

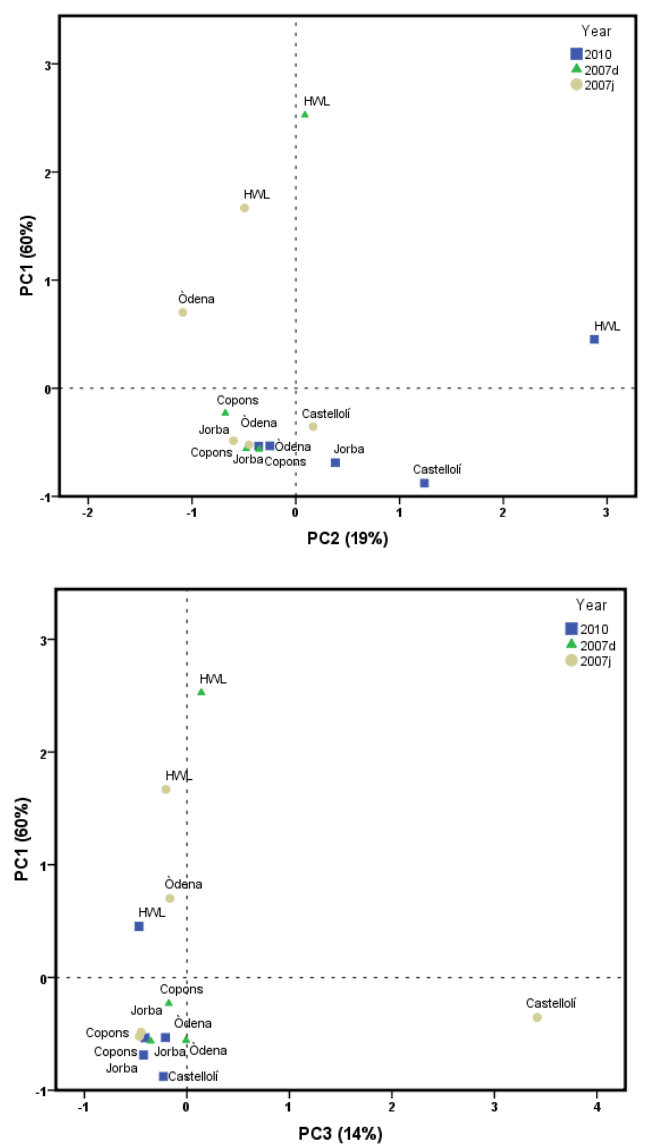

Fig. 3. PCA a) PC1 vs. PC2, and b) $\mathrm{PC} 1$ vs. PC3 of metals and $\mathrm{PCDD} / \mathrm{F}$ congeners in soil. 2007d: samples collected in December 2007; 2007j: samples taken in July 2007.

chlorinated compounds in particular. ${ }^{26}$ Notwithstanding, it must be highlighted that dietary intake is the major route of exposure to POPs, especially through consumption of fish and seafood from contaminated waters. ${ }^{26}$ Considering recent data on the human intake through food for the Catalan population, ${ }^{10}$ the environmental exposure to PCDD/Fs and metals here calculated would only mean less than $0.01 \%$ of the total exposure.

The carcinogenic and non-carcinogenic risks of exposure to heavy metals and PCDD/Fs are summarized in Table 4. The non-carcinogenic risks for metals and PCDD/Fs, expressed as Hazard Quotient (HQ), did not exceed the safety value of 1 in any case. For metals, the highest HQ corresponded to As in the HWL, with values of 0.134 and 0.142 in 2009 and 2010, respectively. As for $\mathrm{PCDD} / \mathrm{Fs}$, the highest $\mathrm{HQ}$ also corresponded to the HWL, ranging from $1.93 \cdot 10^{-4}$ to
$3.88 \cdot 10^{-3}$ in 2009 and 2010, respectively. The carcinogenic risks derived from exposure to metals and PCDD/Fs were below the threshold recommended by the Spanish legislation, which is $10^{-5}$. The only exceptions were $\mathrm{Cr}$ inhalation in Jorba (control site) in 2010, as well as the As dermal absorption and soil ingestion in the HWL in both sampling periods. Anyhow, they were within the range $10^{-6}-10^{-4}$, which is considered as assumable taking into account the differences between individuals. ${ }^{27}$ In addition, two important aspects should be highlighted: 1) although it is generally known that inorganic As is the only carcinogenic species, risk calculations were performed by using total As concentration; 2) background As levels in soils are extremely affected by the regional geology. ${ }^{28}$ With respect to $\mathrm{Cr}$, total levels were also evaluated, but a slope factor is only defined for $\mathrm{Cr}(\mathrm{VI})$, the carcinogenic form. In this case, the risk was estimated by considering that the level of hexavalent chromium was $1 / 6$ of the total $\mathrm{Cr}^{29}$

The above results show that there were not differences in air samples between metal (As, Cd, Cr, $\mathrm{Hg}, \mathrm{Ni}$, and $\mathrm{Pb}$ ) and $\mathrm{PCDD} / \mathrm{F}$ levels measured at the HWL and the near/blank sampling sites. In turn, metal and $\mathrm{PCDD} / \mathrm{F}$ soil levels found inside the HWL were slightly higher than those observed in the other sampling points. Anyway, pollutant levels in samples collected inside and outside the landfill presented different profiles. It would indicate that the HWL is not an important release source of these pollutants in the area under its direct influence. Moreover, the (carcinogenic and non-carcinogenic) health risks for the local residents were considered as acceptable according to national and international regulations. In spite of that, a continuous monitoring is recommended to detect any possible increase in the environmental levels of metals and PCDD/Fs, which might be of concern for both the HWL workers and the population living in the vicinity of the plant.

\section{Acknowledgments}

This study was financially supported by Atlas Gestión Medioambiental, S.A., Spain.

\section{References}

1. M. Cobo, A. Gálvez, J. A. Conesa and C. Montes de Correa, Characterization of fly ash from a hazardous waste incinerator in Medellin, Colombia, J. Hazard. Mater. 168 (2009) 1223-1232. 
2. T. Chung, C. Liao and G. Chang-Chien, Distribution of polycyclic aromatic hydrocarbons and polychlorinated dibenzo-p-dioxins/dibenzofurans in ash from different units in a municipal solid waste incinerator, Waste Manage. Res. 28 (2010) 789-799.

3. J. Yao, W. Li, Q. Kong, Y. Wu, R. He and D. Shen, Content, mobility and transfer behavior of heavy metals in MSWI bottom ash in Zhejiang province, China, Fuel 89 (2010) 616-622.

4. M. Schuhmacher and J. L. Domingo, Long-term study of environmental levels of dioxins and furans in the vicinity of a municipal solid waste incinerator. Environ. Int. 32 (2006) 397-404

5. S. Uğurlu and C. Kahraman, Fuzzy Multicriteria Risk Assessment for hazardous waste management: The case of Istanbul, J. Risk Anal. Crisis Response 1 (2011) 29-41.

6. L. Giusti, A review of waste management practices and their impact on human health, Waste Manage. 29 (2009) 2227 2239.

7. M. Vrijheid, Health effects of residence near hazardous waste landfill sites: A review of epidemiologic literature, Environ.Health Perspect. 108 (2000) 101-112.

8. E. Davoli, E. Fattore, V. Paiano, A. Colombo, M. Palmiotto, A. N. Rossi, M. Il Grande and R. Fanelli, Waste management health risk assessment: A case study of a solid waste landfill in South Italy, Waste Manage. 30 (2010) 16081613.

9. M. Mari, M. Nadal, M. Schuhmacher and J. L. Domingo, Exposure to heavy metals and PCDD/Fs by the population living in the vicinity of a hazardous waste landfill in Catalonia, Spain: Health risk assessment, Environ. Int. 35 (2009) 1034-1039.

10. M. Nadal, M. Schuhmacher and J. L. Domingo, Longterm environmental monitoring of persistent organic pollutants and metals in a chemical/petrochemical area: Human health risks, Environ. Pollut. 159 (2011) 1769-1777.

11. M. Nadal, M. Mari, M. Schuhmacher and J. L. Domingo, Multi-compartmental environmental surveillance of a petrochemical area: Levels of micropollutants, Environ. Int. 35 (2009) 227-235.

12. J. Rovira, M. Mari, M. Nadal, M. Schuhmacher and J. L. Domingo, Environmental monitoring of metals, PCDD/Fs and PCBs as a complementary tool of biological surveillance to assess human health risks, Chemosphere 80 (2010) 11831189 .

13. J. Rovira, V. Linares, M. Bellés, M. Nadal and J. L. Domingo Airborne levels of uranium in the surroundings of various industrial facilities: Human health risks, J. Risk Anal. Crisis Response 1 (2011) 42-47.

14. M. Van den Berg, L.S. Birnbaum, M. Denison, M. De Vito, W. Farland, M. Feeley, H. Fiedler, H. Hakansson, A. Hanberg, L. Haws, M. Rose, S. Safe, D. Schrenk, C. Tohyama, A. Tritscher, J. Tuomisto, M. Tysklind, N. Walker, R.E. Peterson, The 2005 World Health Organization reevaluation of human and Mammalian toxic equivalency factors for dioxins and dioxin-like compounds. Toxicol. Sci. 93 (2006) 223-241.

15. J. Rovira, M. Mari, M. Schuhmacher, M. Nadal and J. L. Domingo, Monitoring environmental pollutants in the vicinity of a cement plant: A temporal study, Arch. Environ. Contam. Toxicol. 60 (2011) 372-384.

16. US EPA, Risk assessment guidance for superfund volume I: human health evaluation manual, United States Environmental Protection Agency, EPA/540/1-89/002, 1989.

17. RAIS, The Risk Assessment Information System, Available at: http://rais.ornl.gov/. Accessed: 7 October 2011.

18. J. Rovira, M. Mari, M. Nadal, M. Schuhmacher and J. L. Domingo, Partial replacement of fossil fuel in a cement plant: Risk assessment for the population living in the neighborhood, Sci. Total Environ. 408 (2010) 5372-5380.

19. E. Abad, K. Martínez, L. Gustems, R. Gómez, X. Guinart, I. Hernández and J. Rivera, Ten years measuring PCDDs/PCDFs in ambient air in Catalonia (Spain), Chemosphere 67 (2007) 1709-1714.

20. M. Onofrio, R. Spataro and S. Botta, The role of a steel plant in north-west Italy to the local air concentrations of PCDD/Fs, Chemosphere 82 (2011) 708-717.

21. ACR, Soil reference levels. Agència Catalana de Residus. Generalitat de Catalunya (in Catalan). Available at: http://www20.gencat.cat/portal/site/arc/, Accessed: 2 June 2011.

22. Eurogeosurveys, Geochemical Atlas of Europe, Available at: www.gsf.fi/publ/foregsatlas/index.php. Accessed: 7 October 2011.

23. US EPA, Review of international soil levels for dioxin. United States Environmental Protection Agency, 9200.3-54. OSWER, 2009.

24. R. Carafa, L. Faggiano, M. Real, A. Munné, A. Ginebreda, H. Guasch, M. Flo, L. Tirapu and P. Carsten von der Ohe, Water toxicity assessment and spatial pollution patterns identification in a Mediterranean River Basin District. Tools for water management and risk analysis, Sci. Total Environ. 409 (2011) 4269-4279.

25. M. Mari, M. Nadal, M. Schuhmacher and J. L. Domingo, Application of self-organizing maps for PCDD/F pattern recognition of environmental and biological samples to evaluate the impact of a hazardous waste incinerator, Environ. Sci. Technol. 44 (2010) 3162-3168.

26. D.O. Carpenter, Polychlorinated biphenyls (PCBs): Routes of exposure and effects on human health, Rev. Environ. Health 21 (2006) 1-23.

27. US EPA, Soil screening guidance: user's guide. United States Environmental Protection Agency, EPA/540/R-96/018, 1996.

28. X. Martinez-Lladó, M. Vilà, V. Martí, M. Rovira, J. A. Domènech and J. D. Pablo, Trace element distribution in topsoils in Catalonia: Background and reference values and relationship with regional geology, Environ. Eng. Sci. 25 (2008) 863-878.

29. M. Nadal, M. Schuhmacher and J. L. Domingo, Metal pollution of soils and vegetation in an area with petrochemical industry, Sci. Total Environ. 321 (2004) 59-69. 